\title{
Formylpeptide receptors in GtoPdb v.2021.2
}

Magnus Bäck ${ }^{1}$, François Boulay ${ }^{2}$, Nan Chiang ${ }^{3}$, Sven-Erik Dahlén ${ }^{1}$, Claes Dahlgren $^{4}$, Jeffrey Drazen ${ }^{5}$, Jilly F. Evans ${ }^{6}$, Craig Gerard ${ }^{7}$, Philip M. Murphy ${ }^{8}$, Marc Parmentier ${ }^{9}$, Mark Quinn ${ }^{10}$, G. Enrico Rovati $^{11}$, Charles N. Serhan ${ }^{5}$, Takao Shimizu ${ }^{12}$, Ji Ming Wang ${ }^{13}$, Richard D. Ye ${ }^{14}$ and Takehiko Yokomizo $^{15}$

1. Karolinska Institutet, Sweden

2. Commissariat à l’Energie Atomique, France

3. Brigham and Women's Hospital, USA

4. University of Göteborg, Sweden

5. Harvard University, USA

6. PharmAkea, USA

7. Harvard Medical School and Children's Hospital, USA

8. National Institutes of Health, USA

9. Université Libre de Bruxelles, Belgium

10. Montana State University, USA

11. University of Milan, Italy

12. University of Tokyo, Japan

13. Frederick National Laboratory for Cancer Research, USA

14. The Chinese University of Hong Kong, Shenzhen, China

15. Juntendo University, Japan

\begin{abstract}
The formylpeptide receptors (nomenclature agreed by the NC-IUPHAR Subcommittee on the formylpeptide receptor family [196]) respond to exogenous ligands such as the bacterial product fMet-Leu-Phe (fMLP) and endogenous ligands such as lipoxin $\mathrm{A}_{4}\left(\mathrm{LXA}_{4}\right)$, 15-epi-lipoxin $\mathrm{A}_{4}$, annexin I , cathepsin $G$, amyloid $\beta 42$, serum amyloid $A$ and spinorphin, derived from $\beta$-haemoglobin. FPR1 also serves as a plague receptor for selective destruction of human immune cells by $Y$. pestis [135]. The FPR1/2 agonists 'compound 17b' and 'compound 43' have shown cardiac protective functions [149, $64]$.
\end{abstract}

\section{Contents}

This is a citation summary for Formylpeptide receptors in the Guide to Pharmacology database (GtoPdb). It exists purely as an adjunct to the database to facilitate the recognition of citations to and from the database by citation analyzers. Readers will almost certainly want to visit the relevant sections of the database which are given here under database links.

GtoPdb is an expert-driven guide to pharmacological targets and the substances that act on them. GtoPdb is a reference work which is most usefully represented as an on-line database. As in any publication this work should be appropriately cited, and the papers it cites should also be recognized. This document provides a citation for the relevant parts of the database, and also provides a reference list for the research cited by those parts. For further details see [18].

Please note that the database version for the citations given in GtoPdb are to the most recent preceding version in which the family or its subfamilies and targets were substantially changed. The links below are to the current version. If you need to consult the cited version, rather than the most recent version, please contact the GtoPdb curators.

\section{Database links}

Formylpeptide receptors

https://www.guidetopharmacology.org/GRAC/FamilyDisplayForward?familyId=23 
Introduction to Formylpeptide receptors

https://www.guidetopharmacology.org/GRAC/FamilyIntroductionForward?familyId=23

Receptors

FPR1

https://www.guidetopharmacology.org/GRAC/ObjectDisplayForward?objectId=222

FPR2/ALX

https://www.guidetopharmacology.org/GRAC/ObjectDisplayForward?objectId=223 FPR3

https://www.guidetopharmacology.org/GRAC/ObjectDisplayForward?objectId=224

\section{References}

1. Amatruda TT, Dragas-Graonic S, Holmes R and Perez HD. (1995) Signal transduction by the formyl peptide receptor. Studies using chimeric receptors and site-directed mutagenesis define a novel domain for interaction with G-proteins. J Biol Chem 270: 28010-3 [PMID:7499283]

2. Ariel A, Chiang N, Arita M, Petasis NA and Serhan CN. (2003) Aspirin-triggered lipoxin A4 and B4 analogs block extracellular signal-regulated kinase-dependent TNF-alpha secretion from human T cells. J Immunol 170: 6266-72 [PMID:12794159]

3. Arterburn JB, Oprea TI, Prossnitz ER, Edwards BS and Sklar LA. (2009) Discovery of selective probes and antagonists for G-protein-coupled receptors FPR/FPRL1 and GPR30. Curr Top Med Chem 9: 1227-36 [PMID:19807662]

4. Asahina Y, Wurtz NR, Arakawa K, Carson N, Fujii K, Fukuchi K, Garcia R, Hsu MY, Ishiyama J and Ito B et al.. (2020) Discovery of BMS-986235/LAR-1219: A Potent Formyl Peptide Receptor 2 (FPR2) Selective Agonist for the Prevention of Heart Failure. J Med Chem 63: 9003-9019 [PMID:32407089]

5. Bae YS, Lee HY, Jo EJ, Kim JI, Kang HK, Ye RD, Kwak JY and Ryu SH. (2004) Identification of peptides that antagonize formyl peptide receptor-like 1-mediated signaling. J Immunol 173: 60714 [PMID:15210823]

6. Bao L, Gerard NP, Eddy RL Jr, Shows TB and Gerard C. (1992) Mapping of genes for the human C5a receptor (C5AR), human FMLP receptor (FPR), and two FMLP receptor homologue orphan receptors (FPRH1, FPRH2) to chromosome 19. Genomics 13: 437-440 [PMID:1612600]

7. Becker EL, Forouhar FA, Grunnet ML, Boulay F, Tardif M, Bormann BJ, Sodja D, Ye RD, Woska JR and Murphy PM. (1998) Broad immunocytochemical localization of the formylpeptide receptor in human organs, tissues, and cells. Cell Tissue Res 292: 129-35 [PMID:9506920]

8. Bellner L, Thorén F, Nygren E, Liljeqvist JA, Karlsson A and Eriksson K. (2005) A proinflammatory peptide from herpes simplex virus type 2 glycoprotein $\mathrm{G}$ affects neutrophil, monocyte, and NK cell functions. J Immunol 174: 2235-41 [PMID:15699157]

9. Bentwood BJ and Henson PM. (1980) The sequential release of granule constitutents from human neutrophils. J Immunol 124: 855-62 [PMID:6153206]

10. Betten A, Bylund J, Christophe T, Cristophe T, Boulay F, Romero A, Hellstrand K and Dahlgren C. (2001) A proinflammatory peptide from Helicobacter pylori activates monocytes to induce lymphocyte dysfunction and apoptosis. J Clin Invest 108: 1221-8 [PMID:11602630]

11. Billah MM, Eckel S, Mullmann TJ, Egan RW and Siegel MI. (1989) Phosphatidylcholine hydrolysis by phospholipase D determines phosphatidate and diglyceride levels in chemotactic peptide-stimulated human neutrophils. Involvement of phosphatidate phosphohydrolase in signal transduction. J Biol Chem 264: 17069-77 [PMID:2793844]

12. Bokoch GM and Gilman AG. (1984) Inhibition of receptor-mediated release of arachidonic acid by pertussis toxin. Cell 39: 301-8 [PMID:6094010]

13. Boulay F, Tardif M, Brouchon L and Vignais P. (1990) Synthesis and use of a novel N-formyl peptide derivative to isolate a human N-formyl peptide receptor cDNA. Biochem Biophys Res Commun 168: 1103-9 [PMID:2161213]

14. Boulay F, Tardif M, Brouchon L and Vignais P. (1990) The human N-formylpeptide receptor. Characterization of two cDNA isolates and evidence for a new subfamily of G-protein-coupled receptors. Biochemistry 29: 11123-33 [PMID:2176894]

15. Bozinovski S, Anthony D, Anderson GP, Irving LB, Levy BD and Vlahos R. (2013) Treating neutrophilic inflammation in COPD by targeting ALX/FPR2 resolution pathways. Pharmacol Ther 140: 280-9 [PMID:23880288]

16. Bozinovski S, Anthony D and Vlahos R. (2014) Targeting pro-resolution pathways to combat chronic inflammation in COPD. J Thorac Dis 6: 1548-56 [PMID:25478196]

17. Brancaleone V, Gobbetti T, Cenac N, le Faouder P, Colom B, Flower RJ, Vergnolle N, Nourshargh S and Perretti M. (2013) A vasculo-protective circuit centered on lipoxin A4 and aspirin-triggered 15-epi-lipoxin A4 operative in murine microcirculation. Blood 122: 608-17 [PMID:23733341]

18. Buneman P, Christie G, Davies JA, Dimitrellou R, Harding SD, Pawson AJ, Sharman JL and Wu Y. (2020) Why data citation isn't working, and what to do about it Database 2020 
[PMID:32367113]

19. Bürli RW, Xu H, Zou X, Muller K, Golden J, Frohn M, Adlam M, Plant MH, Wong M and McElvain $\mathrm{M}$ et al.. (2006) Potent hFPRL1 (ALXR) agonists as potential anti-inflammatory agents. Bioorg Med Chem Lett 16: 3713-8 [PMID:16697190]

20. Campbell JJ, Qin S, Bacon KB, Mackay CR and Butcher EC. (1996) Biology of chemokine and classical chemoattractant receptors: differential requirements for adhesion-triggering versus chemotactic responses in lymphoid cells. J Cell Biol 134: 255-66 [PMID:8698820]

21. Carp H. (1982) Mitochondrial N-formylmethionyl proteins as chemoattractants for neutrophils. $J$ Exp Med 155: 264-75 [PMID:6274994]

22. Cattaneo F, Parisi M and Ammendola R. (2013) Distinct signaling cascades elicited by different formyl Peptide receptor 2 (FPR2) agonists. Int J Mol Sci 14: 7193-230 [PMID:23549262]

23. Cevik-Aras H, Kalderén C, Jenmalm Jensen A, Oprea T, Dahlgren C and Forsman H. (2012) A non-peptide receptor inhibitor with selectivity for one of the neutrophil formyl peptide receptors, FPR 1. Biochem Pharmacol 83: 1655-62 [PMID:22410002]

24. Chen J, Bernstein HS, Chen M, Wang L, Ishii M, Turck CW and Coughlin SR. (1995) Tethered ligand library for discovery of peptide agonists. J Biol Chem 270: 23398-401 [PMID:7559498]

25. Chen K, Le Y, Liu Y, Gong W, Ying G, Huang J, Yoshimura T, Tessarollo L and Wang JM. (2010) A critical role for the $\mathrm{g}$ protein-coupled receptor mFPR2 in airway inflammation and immune responses. J Immunol 184: 3331-5 [PMID:20200280]

26. Chen K, Liu M, Liu Y, Yoshimura T, Shen W, Le Y, Durum S, Gong W, Wang C and Gao JL et al.. (2013) Formylpeptide receptor-2 contributes to colonic epithelial homeostasis, inflammation, and tumorigenesis. J Clin Invest 123: 1694-704 [PMID:23454745]

27. Chen T, Xiong M, Zong X, Ge Y, Zhang H, Wang M, Won Han G, Yi C, Ma L and Ye RD et al.. (2020) Structural basis of ligand binding modes at the human formyl peptide receptor 2. Nat Commun 11: 1208 [PMID:32139677]

28. Chen X, Mellon RD, Yang L, Dong H, Oppenheim JJ and Howard OM. (2002) Regulatory effects of deoxycholic acid, a component of the anti-inflammatory traditional Chinese medicine Niuhuang, on human leukocyte response to chemoattractants. Biochem Pharmacol 63: 533-41 [PMID:11853704]

29. Chen X, Yang D, Shen W, Dong HF, Wang JM, Oppenheim JJ and Howard MZ. (2000) Characterization of chenodeoxycholic acid as an endogenous antagonist of the G-coupled formyl peptide receptors. Inflamm Res 49: 744-55 [PMID:11211928]

30. Chiang N, Fierro IM, Gronert K and Serhan CN. (2000) Activation of lipoxin A(4) receptors by aspirin-triggered lipoxins and select peptides evokes ligand-specific responses in inflammation. $J$ Exp Med 191: 1197-208 [PMID:10748237]

31. Chiang N, Serhan CN, Dahlén SE, Drazen JM, Hay DW, Rovati GE, Shimizu T, Yokomizo T and Brink C. (2006) The lipoxin receptor ALX: potent ligand-specific and stereoselective actions in vivo. Pharmacol Rev 58: 463-87 [PMID:16968948]

32. Chiang N, Takano T, Arita M, Watanabe S and Serhan CN. (2003) A novel rat lipoxin A4 receptor that is conserved in structure and function. Br J Pharmacol 139: 89-98 [PMID:12746227]

33. Christophe T, Karlsson A, Dugave C, Rabiet MJ, Boulay F and Dahlgren C. (2001) The synthetic peptide Trp-Lys-Tyr-Met-Val-Met-NH2 specifically activates neutrophils through FPRL1/lipoxin A4 receptors and is an agonist for the orphan monocyte-expressed chemoattractant receptor FPRL2.J Biol Chem 276: 21585-93 [PMID:11285256]

34. Cilibrizzi A, Schepetkin IA, Bartolucci G, Crocetti L, Dal Piaz V, Giovannoni MP, Graziano A, Kirpotina LN, Quinn MT and Vergelli C. (2012) Synthesis, enantioresolution, and activity profile of chiral 6-methyl-2,4-disubstituted pyridazin-3(2H)-ones as potent N-formyl peptide receptor agonists. Bioorg Med Chem 20: 3781-92 [PMID:22607879]

35. Clish CB, O'Brien JA, Gronert K, Stahl GL, Petasis NA and Serhan CN. (1999) Local and systemic delivery of a stable aspirin-triggered lipoxin prevents neutrophil recruitment in vivo. Proc Natl Acad Sci USA 96: 8247-52 [PMID:10393980]

36. Cooray SN, Gobbetti T, Montero-Melendez T, McArthur S, Thompson D, Clark AJ, Flower RJ and Perretti M. (2013) Ligand-specific conformational change of the G-protein-coupled receptor ALX/FPR2 determines proresolving functional responses. Proc Natl Acad Sci USA 110: 18232-7 [PMID:24108355]

37. Czapiga M, Gao JL, Kirk A and Lekstrom-Himes J. (2005) Human platelets exhibit chemotaxis using functional N-formyl peptide receptors. Exp Hematol 33: 73-84 [PMID:15661400]

38. D'Acquisto F, Paschalidis N, Sampaio AL, Merghani A, Flower RJ and Perretti M. (2007) Impaired $\mathrm{T}$ cell activation and increased Th2 lineage commitment in Annexin-1-deficient T cells. Eur J Immunol 37: 3131-42 [PMID:17948261]

39. de Gaetano M, Butler E, Gahan K, Zanetti A, Marai M, Chen J, Cacace A, Hams E, Maingot C and McLoughlin A et al.. (2019) Asymmetric synthesis and biological evaluation of imidazoleand oxazole-containing synthetic lipoxin $\mathrm{A}_{4}$ mimetics (sLXms). Eur J Med Chem 162: 80-108 [PMID:30419493] 
40. De Yang, Chen Q, Schmidt AP, Anderson GM, Wang JM, Wooters J, Oppenheim JJ and Chertov O. (2000) LL-37, the neutrophil granule- and epithelial cell-derived cathelicidin, utilizes formyl peptide receptor-like 1 (FPRL1) as a receptor to chemoattract human peripheral blood neutrophils, monocytes, and T cells. J Exp Med 192: 1069-74 [PMID:11015447]

41. Deng X, Ueda H, Su SB, Gong W, Dunlop NM, Gao JL, Murphy PM and Wang JM. (1999) A synthetic peptide derived from human immunodeficiency virus type $1 \mathrm{gp} 120$ downregulates the expression and function of chemokine receptors CCR5 and CXCR4 in monocytes by activating the 7-transmembrane G-protein-coupled receptor FPRL1/LXA4R. Blood 94: 1165-73 [PMID:10438703]

42. Derian CK, Solomon HF, Higgins 3rd JD, Beblavy MJ, Santulli RJ, Bridger GJ, Pike MC, Kroon DJ and Fischman AJ. (1996) Selective inhibition of N-formylpeptide-induced neutrophil activation by carbamate-modified peptide analogues. Biochemistry 35: 1265-9 [PMID:8573582]

43. Devchand PR, Arita M, Hong S, Bannenberg G, Moussignac RL, Gronert K and Serhan CN. (2003) Human ALX receptor regulates neutrophil recruitment in transgenic mice: roles in inflammation and host defense. FASEB J 17: 652-9 [PMID:12665478]

44. Dufton N, Hannon R, Brancaleone V, Dalli J, Patel HB, Gray M, D'Acquisto F, Buckingham JC, Perretti M and Flower RJ. (2010) Anti-inflammatory role of the murine formyl-peptide receptor 2: ligand-specific effects on leukocyte responses and experimental inflammation. J Immunol 184: 2611-9 [PMID:20107188]

45. Eckhardt K, Roth P, Günter T, Schmidt S and Feuerstein TJ. (2003) Differential effects of K(ATP) channel blockers on [(3)H]-noradrenaline overflow after short- and long-term exposure to (+)oxaprotiline or desipramine. Naunyn Schmiedebergs Arch Pharmacol 367: 168-75 [PMID:12595958]

46. Edwards BS, Bologa C, Young SM, Balakin KV, Prossnitz ER, Savchuck NP, Sklar LA and Oprea TI. (2005) Integration of virtual screening with high-throughput flow cytometry to identify novel small molecule formylpeptide receptor antagonists. Mol Pharmacol 68: 1301-10 [PMID:16118363]

47. El Shamieh S, Herbeth B, Azimi-Nezhad M, Benachour H, Masson C and Visvikis-Siest S. (2012) Human formyl peptide receptor 1 C32T SNP interacts with age and is associated with blood pressure levels. Clin Chim Acta 413: 34-8 [PMID:21144844]

48. Elagoz A, Henderson D, Babu PS, Salter S, Grahames C, Bowers L, Roy MO, Laplante P, Grazzini E and Ahmad S et al.. (2004) A truncated form of CKbeta8-1 is a potent agonist for human formyl peptide-receptor-like 1 receptor. Br J Pharmacol 141: 37-46 [PMID:14662730]

49. Ernst S, Lange C, Wilbers A, Goebeler V, Gerke V and Rescher U. (2004) An annexin 1 Nterminal peptide activates leukocytes by triggering different members of the formyl peptide receptor family. J Immunol 172: 7669-76 [PMID:15187149]

50. Filep JG, Zouki C, Petasis NA, Hachicha M and Serhan CN. (1999) Anti-inflammatory actions of lipoxin A(4) stable analogs are demonstrable in human whole blood: modulation of leukocyte adhesion molecules and inhibition of neutrophil-endothelial interactions. Blood 94: 4132-42 [PMID:10590058]

51. Fiore S, Maddox JF, Perez HD and Serhan CN. (1994) Identification of a human cDNA encoding a functional high affinity lipoxin A4 receptor. J Exp Med 180: 253-60 [PMID:8006586]

52. Fiore S, Romano M, Reardon EM and Serhan CN. (1993) Induction of functional lipoxin A4 receptors in HL-60 cells. Blood 81: 3395-403 [PMID:8389617]

53. Fiore S, Ryeom SW, Weller PF and Serhan CN. (1992) Lipoxin recognition sites. Specific binding of labeled lipoxin A4 with human neutrophils. J Biol Chem 267: 16168-76 [PMID:1322894]

54. Fiore S and Serhan CN. (1995) Lipoxin A4 receptor activation is distinct from that of the formyl peptide receptor in myeloid cells: inhibition of CD11/18 expression by lipoxin A4-lipoxin A4 receptor interaction. Biochemistry 34: 16678-86 [PMID:8527441]

55. Forsman H, Andréasson E, Karlsson J, Boulay F, Rabiet MJ and Dahlgren C. (2012) Structural characterization and inhibitory profile of formyl peptide receptor 2 selective peptides descending from a PIP2-binding domain of gelsolin. J Immunol 189: 629-37 [PMID:22706076]

56. Forsman H and Dahlgren C. (2009) Lipoxin A(4) metabolites/analogues from two commercial sources have no effects on TNF-alpha-mediated priming or activation through the neutrophil formyl peptide receptors. Scand J Immunol 70: 396-402 [PMID:19751275]

57. Freer RJ, Day AR, Muthukumaraswamy N, Pinon D, Wu A, Showell HJ and Becker EL. (1982) Formyl peptide chemoattractants: a model of the receptor on rabbit neutrophils. Biochemistry 21: 257-63 [PMID:6280748]

58. Freer RJ, Day AR, Radding JA, Schiffmann E, Aswanikumar S, Showell HJ and Becker EL. (1980) Further studies on the structural requirements for synthetic peptide chemoattractants. Biochemistry 19: 2404-10 [PMID:7387981]

59. Fu H, Björkman L, Janmey P, Karlsson A, Karlsson J, Movitz C and Dahlgren C. (2004) The two neutrophil members of the formylpeptide receptor family activate the NADPH-oxidase through signals that differ in sensitivity to a gelsolin derived phosphoinositide-binding peptide. BMC Cell Biol 5: 50 [PMID:15625007] 
60. Gao JL, Chen H, Filie JD, Kozak CA and Murphy PM. (1998) Differential expansion of the Nformylpeptide receptor gene cluster in human and mouse. Genomics 51: 270-6 [PMID:9722950]

61. Gao JL, Guillabert A, Hu J, Le Y, Urizar E, Seligman E, Fang KJ, Yuan X, Imbault V and Communi D et al.. (2007) F2L, a peptide derived from heme-binding protein, chemoattracts mouse neutrophils by specifically activating Fpr2, the low-affinity $\mathrm{N}$-formylpeptide receptor. J Immunol 178: 1450-6 [PMID:17237393]

62. Gao JL, Lee EJ and Murphy PM. (1999) Impaired antibacterial host defense in mice lacking the N-formylpeptide receptor. J Exp Med 189: 657-62 [PMID:9989980]

63. Gao JL, Schneider EH, Dimitrov EL, Haun F, Pham TM, Mohammed AH, Usdin TB and Murphy PM. (2011) Reduced fear memory and anxiety-like behavior in mice lacking formylpeptide receptor 1. Behav Genet 41: 724-33 [PMID:21484271]

64. García RA, Ito BR, Lupisella JA, Carson NA, Hsu MY, Fernando G, Heroux M, Bouvier M, Dierks E and Kick EK et al.. (2019) Preservation of Post-Infarction Cardiac Structure and Function via Long-Term Oral Formyl Peptide Receptor Agonist Treatment. JACC Basic Transl Sci 4: 905-920 [PMID:31909300]

65. Gavins FN, Yona S, Kamal AM, Flower RJ and Perretti M. (2003) Leukocyte antiadhesive actions of annexin 1: ALXR- and FPR-related anti-inflammatory mechanisms. Blood 101: 4140-7 [PMID:12560218]

66. Ge Y, Zhang S, Wang J, Xia F, Wan JB, Lu J and Ye RD. (2020) Dual modulation of formyl peptide receptor 2 by aspirin-triggered lipoxin contributes to its anti-inflammatory activity. FASEB J 34: 6920-6933 [PMID:32239559]

67. Gewirtz AT, Collier-Hyams LS, Young AN, Kucharzik T, Guilford WJ, Parkinson JF, Williams IR, Neish AS and Madara JL. (2002) Lipoxin a4 analogs attenuate induction of intestinal epithelial proinflammatory gene expression and reduce the severity of dextran sodium sulfate-induced colitis. J Immunol 168: 5260-7 [PMID:11994483]

68. Gilman AG. (1987) G proteins: transducers of receptor-generated signals. Annu Rev Biochem 56: 615-49 [PMID:3113327]

69. Godson C, Mitchell S, Harvey K, Petasis NA, Hogg N and Brady HR. (2000) Cutting edge: lipoxins rapidly stimulate nonphlogistic phagocytosis of apoptotic neutrophils by monocytederived macrophages. J Immunol 164: 1663-7 [PMID:10657608]

70. Gronert K, Martinsson-Niskanen T, Ravasi S, Chiang N and Serhan CN. (2001) Selectivity of recombinant human leukotriene $\mathrm{D}(4)$, leukotriene $\mathrm{B}(4)$, and lipoxin $\mathrm{A}(4)$ receptors with aspirintriggered 15-epi-LXA(4) and regulation of vascular and inflammatory responses. Am J Pathol 158: 3-9 [PMID:11141472]

71. Guilford WJ, Bauman JG, Skuballa W, Bauer S, Wei GP, Davey D, Schaefer C, Mallari C, Terkelsen J and Tseng JL et al.. (2004) Novel 3-oxa lipoxin A4 analogues with enhanced chemical and metabolic stability have anti-inflammatory activity in vivo. J Med Chem 47: 2157-65 [PMID:15056011]

72. Gwinn MR, Sharma A and De Nardin E. (1999) Single nucleotide polymorphisms of the N-formyl peptide receptor in localized juvenile periodontitis. J Periodontol 70: 1194-201 [PMID:10534074]

73. Haas PJ, de Haas CJ, Kleibeuker W, Poppelier MJ, van Kessel KP, Kruijtzer JA, Liskamp RM and van Strijp JA. (2004) N-terminal residues of the chemotaxis inhibitory protein of Staphylococcus aureus are essential for blocking formylated peptide receptor but not C5a receptor. J Immunol 173: 5704-11 [PMID:15494522]

74. Hanson J, Ferreirós N, Pirotte B, Geisslinger G and Offermanns S. (2013) Heterologously expressed formyl peptide receptor 2 (FPR2/ALX) does not respond to lipoxin A4. Biochem Pharmacol 85: 1795-802 [PMID:23643932]

75. Harada M, Habata Y, Hosoya M, Nishi K, Fujii R, Kobayashi M and Hinuma S. (2004) NFormylated humanin activates both formyl peptide receptor-like 1 and 2. Biochem Biophys Res Commun 324: 255-61 [PMID:15465011]

76. Hartt JK, Barish G, Murphy PM and Gao JL. (1999) N-formylpeptides induce two distinct concentration optima for mouse neutrophil chemotaxis by differential interaction with two Nformylpeptide receptor (FPR) subtypes. Molecular characterization of FPR2, a second mouse neutrophil FPR. J Exp Med 190: 741-7 [PMID:10477558]

77. Hartt JK, Liang T, Sahagun-Ruiz A, Wang JM, Gao JL and Murphy PM. (2000) The HIV-1 cell entry inhibitor T-20 potently chemoattracts neutrophils by specifically activating the Nformylpeptide receptor. Biochem Biophys Res Commun 272: 699-704 [PMID:10860818]

78. Hayhoe RP, Kamal AM, Solito E, Flower RJ, Cooper D and Perretti M. (2006) Annexin 1 and its bioactive peptide inhibit neutrophil-endothelium interactions under flow: indication of distinct receptor involvement. Blood 107: 2123-30 [PMID:16278303]

79. He HQ, Liao D, Wang ZG, Wang ZL, Zhou HC, Wang MW and Ye RD. (2013) Functional characterization of three mouse formyl peptide receptors. Mol Pharmacol 83: 389-98 [PMID:23160941]

80. He HQ, Troksa EL, Caltabiano G, Pardo L and Ye RD. (2014) Structural determinants for the 
interaction of formyl peptide receptor 2 with peptide ligands. J Biol Chem 289: 2295-306 [PMID:24285541]

81. He R, Sang H and Ye RD. (2003) Serum amyloid A induces IL-8 secretion through a G proteincoupled receptor, FPRL1/LXA4R. Blood 101: 1572-81 [PMID:12393391]

82. He R, Tan L, Browning DD, Wang JM and Ye RD. (2000) The synthetic peptide Trp-Lys-Tyr-MetVal-D-Met is a potent chemotactic agonist for mouse formyl peptide receptor. J Immunol 165: 4598-605 [PMID:11035102]

83. Hecht I, Rong J, Sampaio AL, Hermesh C, Rutledge C, Shemesh R, Toporik A, Beiman M, Dassa $\mathrm{L}$ and Niv $\mathrm{H}$ et al.. (2009) A novel peptide agonist of formyl-peptide receptor-like 1 (ALX) displays anti-inflammatory and cardioprotective effects. J Pharmacol Exp Ther 328: 426-34 [PMID:19023040]

84. Honda S, Campbell JJ, Andrew DP, Engelhardt B, Butcher BA, Warnock RA, Ye RD and Butcher EC. (1994) Ligand-induced adhesion to activated endothelium and to vascular cell adhesion molecule-1 in lymphocytes transfected with the $\mathrm{N}$-formyl peptide receptor. J Immunol 152: 4026-35 [PMID:7511663]

85. Hu JY, Le Y, Gong W, Dunlop NM, Gao JL, Murphy PM and Wang JM. (2001) Synthetic peptide MMK-1 is a highly specific chemotactic agonist for leukocyte FPRL1. J Leukoc Biol 70: 155-61 [PMID:11435499]

86. Jiang H, Kuang Y, Wu Y, Smrcka A, Simon MI and Wu D. (1996) Pertussis toxin-sensitive activation of phospholipase C by the C5a and fMet-Leu-Phe receptors. J Biol Chem 271: 13430-4 [PMID:8662841]

87. Jones BE, Miettinen HM, Jesaitis AJ and Mills JS. (2003) Mutations of F110 and C126 of the formyl peptide receptor interfere with G-protein coupling and chemotaxis. J Periodontol 74: 47584 [PMID:12747452]

88. Karlsson J, Fu H, Boulay F, Dahlgren C, Hellstrand K and Movitz C. (2005) Neutrophil NADPHoxidase activation by an annexin AI peptide is transduced by the formyl peptide receptor (FPR), whereas an inhibitory signal is generated independently of the FPR family receptors. $J$ Leukoc Biol 78: 762-71 [PMID:15951351]

89. Khlebnikov AI, Schepetkin IA, Kirpotina LN, Brive L, Dahlgren C, Jutila MA and Quinn MT. (2012) Molecular docking of 2-(benzimidazol-2-ylthio)-N-phenylacetamide-derived smallmolecule agonists of human formyl peptide receptor 1. J Mol Model 18: 2831-43 [PMID:22127612]

90. Kim HJ, Cho SH, Park JS, Lee TH, Lee EJ, Kim YH, Uh ST, Chung IY, Kim MK and Choi IS et al.. (2012) Association analysis of formyl peptide receptor 2 (FPR2) polymorphisms and aspirin exacerbated respiratory diseases. J Hum Genet 57: 247-53 [PMID:22377711]

91. Kirpotina LN, Khlebnikov AI, Schepetkin IA, Ye RD, Rabiet MJ, Jutila MA and Quinn MT. (2010) Identification of novel small-molecule agonists for human formyl peptide receptors and pharmacophore models of their recognition. Mol Pharmacol 77: 159-70 [PMID:19903830]

92. Klein C, Paul JI, Sauvé K, Schmidt MM, Arcangeli L, Ransom J, Trueheart J, Manfredi JP, Broach JR and Murphy AJ. (1998) Identification of surrogate agonists for the human FPRL-1 receptor by autocrine selection in yeast. Nat Biotechnol 16: 1334-7 [PMID:9853614]

93. Koo C, Lefkowitz RJ and Snyderman R. (1982) The oligopeptide chemotactic factor receptor on human polymorphonuclear leukocyte membranes exists in two affinity states. Biochem Biophys Res Commun 106: 442-449 [PMID:6285921]

94. Krause KH, Schlegel W, Wollheim CB, Andersson T, Waldvogel FA and Lew PD. (1985) Chemotactic peptide activation of human neutrophils and HL-60 cells. Pertussis toxin reveals correlation between inositol trisphosphate generation, calcium ion transients, and cellular activation. J Clin Invest 76: 1348-54 [PMID:3877077]

95. Kretschmer D, Gleske AK, Rautenberg M, Wang R, Köberle M, Bohn E, Schöneberg T, Rabiet MJ, Boulay F and Klebanoff SJ et al.. (2010) Human formyl peptide receptor 2 senses highly pathogenic Staphylococcus aureus. Cell Host Microbe 7: 463-73 [PMID:20542250]

96. Krishnamoorthy S, Recchiuti A, Chiang N, Fredman G and Serhan CN. (2012) Resolvin D1 receptor stereoselectivity and regulation of inflammation and proresolving microRNAs. Am J Pathol 180: 2018-27 [PMID:22449948]

97. Krishnamoorthy S, Recchiuti A, Chiang N, Yacoubian S, Lee CH, Yang R, Petasis NA and Serhan CN. (2010) Resolvin D1 binds human phagocytes with evidence for proresolving receptors. Proc Natl Acad Sci USA 107: 1660-5 [PMID:20080636]

98. Kucharzik T, Gewirtz AT, Merlin D, Madara JL and Williams IR. (2003) Lateral membrane LXA4 receptors mediate LXA4's anti-inflammatory actions on intestinal epithelium. Am J Physiol, Cell Physiol 284: C888-96 [PMID:12456400]

99. Kurosaka K, Chen Q, Yarovinsky F, Oppenheim JJ and Yang D. (2005) Mouse cathelin-related antimicrobial peptide chemoattracts leukocytes using formyl peptide receptor-like 1/mouse formyl peptide receptor-like 2 as the receptor and acts as an immune adjuvant. J Immunol 174: 6257-65 [PMID:15879124]

100. Lacy M, Jones J, Whittemore SR, Haviland DL, Wetsel RA and Barnum SR. (1995) Expression of 
the receptors for the C5a anaphylatoxin, interleukin-8 and FMLP by human astrocytes and microglia. J Neuroimmunol 61: 71-8 [PMID:7560015]

101. Lad PM, Olson CV and Smiley PA. (1985) Association of the N-formyl-Met-Leu-Phe receptor in human neutrophils with a GTP-binding protein sensitive to pertussis toxin. Proc Natl Acad Sci USA 82: 869-73 [PMID:2983319]

102. Le Y, Gong W, Li B, Dunlop NM, Shen W, Su SB, Ye RD and Wang JM. (1999) Utilization of two seven-transmembrane, G protein-coupled receptors, formyl peptide receptor-like 1 and formyl peptide receptor, by the synthetic hexapeptide WKYMVm for human phagocyte activation. $J$ Immunol 163: 6777-84 [PMID:10586077]

103. Le Y, Gong W, Tiffany HL, Tumanov A, Nedospasov S, Shen W, Dunlop NM, Gao JL, Murphy PM and Oppenheim JJ et al.. (2001) Amyloid (beta)42 activates a G-protein-coupled chemoattractant receptor, FPR-like-1.J Neurosci 21: RC123 [PMID:11160457]

104. Le Y, Hu J, Gong W, Shen W, Li B, Dunlop NM, Halverson DO, Blair DG and Wang JM. (2000) Expression of functional formyl peptide receptors by human astrocytoma cell lines. $J$ Neuroimmunol 111: 102-8 [PMID:11063827]

105. Le Y, Iribarren $P$, Zhou Y, Gong W, Hu J, Zhang X and Wang JM. (2004) Silencing the formylpeptide receptor FPR by short-interfering RNA. Mol Pharmacol 66: 1022-8 [PMID:15258259]

106. Le Y, Jiang S, Hu J, Gong W, Su S, Dunlop NM, Shen W, Li B and Ming Wang J. (2000) N36, a synthetic N-terminal heptad repeat domain of the HIV-1 envelope protein gp41, is an activator of human phagocytes. Clin Immunol 96: 236-42 [PMID:10964542]

107. Le Y, Murphy PM and Wang JM. (2002) Formyl-peptide receptors revisited. Trends Immunol 23: 541-8 [PMID:12401407]

108. Lee HY, Kim MK, Park KS, Bae YH, Yun J, Park JI, Kwak JY and Bae YS. (2005) Serum amyloid A stimulates matrix-metalloproteinase-9 upregulation via formyl peptide receptor like-1-mediated signaling in human monocytic cells. Biochem Biophys Res Commun 330: 989-98 [PMID:15809093]

109. Lehman N, Di Fulvio M, McCray N, Campos I, Tabatabaian F and Gomez-Cambronero J. (2006) Phagocyte cell migration is mediated by phospholipases PLD1 and PLD2. Blood 108: 3564-72 [PMID:16873675]

110. Levy BD, Fokin VV, Clark JM, Wakelam MJ, Petasis NA and Serhan CN. (1999) Polyisoprenyl phosphate (PIPP) signaling regulates phospholipase D activity: a 'stop' signaling switch for aspirin-triggered lipoxin A4. FASEB J 13: 903-11 [PMID:10224233]

111. Liang TS, Gao JL, Fatemi O, Lavigne M, Leto TL and Murphy PM. (2001) The endogenous opioid spinorphin blocks fMet-Leu-Phe-induced neutrophil chemotaxis by acting as a specific antagonist at the $\mathrm{N}$-formylpeptide receptor subtype FPR. J Immunol 167: 6609-14 [PMID:11714831]

112. Liu M, Chen K, Yoshimura T, Liu Y, Gong W, Wang A, Gao JL, Murphy PM and Wang JM. (2012) Formylpeptide receptors are critical for rapid neutrophil mobilization in host defense against Listeria monocytogenes. Sci Rep 2: 786 [PMID:23139859]

113. Maddox JF, Hachicha M, Takano T, Petasis NA, Fokin VV and Serhan CN. (1997) Lipoxin A4 stable analogs are potent mimetics that stimulate human monocytes and THP-1 cells via a Gprotein-linked lipoxin A4 receptor. J Biol Chem 272: 6972-8 [PMID:9054386]

114. Maddox JF and Serhan CN. (1996) Lipoxin A4 and B4 are potent stimuli for human monocyte migration and adhesion: selective inactivation by dehydrogenation and reduction. J Exp Med 183: 137-46 [PMID:8551217]

115. Mahomed AG and Anderson R. (2000) Activation of human neutrophils with chemotactic peptide, opsonized zymosan and the calcium ionophore A23187, but not with a phorbol ester, is accompanied by efflux and store-operated influx of calcium. Inflammation 24: 559-69 [PMID:11128053]

116. Maney P, Emecen P, Mills JS and Walters JD. (2009) Neutrophil formylpeptide receptor single nucleotide polymorphism 348T $>C$ in aggressive periodontitis. J Periodontol 80: 492-8 [PMID:19254133]

117. Maney P and Walters JD. (2009) Formylpeptide receptor single nucleotide polymorphism $348 \mathrm{~T}>\mathrm{C}$ and its relationship to polymorphonuclear leukocyte chemotaxis in aggressive periodontitis. J Periodontol 80: 1498-505 [PMID:19722801]

118. Marasco WA, Phan SH, Krutzsch H, Showell HJ, Feltner DE, Nairn R, Becker EL and Ward PA. (1984) Purification and identification of formyl-methionyl-leucyl-phenylalanine as the major peptide neutrophil chemotactic factor produced by Escherichia coli. J Biol Chem 259: 5430-9 [PMID:6371005]

119. Marshall J, Krump E, Lindsay T, Downey G, Ford DA, Zhu P, Walker P and Rubin B. (2000) Involvement of cytosolic phospholipase A2 and secretory phospholipase A2 in arachidonic acid release from human neutrophils. J Immunol 164: 2084-91 [PMID:10657662]

120. McCoy R, Haviland DL, Molmenti EP, Ziambaras T, Wetsel RA and Perlmutter DH. (1995) Nformylpeptide and complement $\mathrm{C} 5$ a receptors are expressed in liver cells and mediate hepatic 
acute phase gene regulation. J Exp Med 182: 207-17 [PMID:7540650]

121. McDonald B, Pittman K, Menezes GB, Hirota SA, Slaba I, Waterhouse CC, Beck PL, Muruve DA and Kubes P. (2010) Intravascular danger signals guide neutrophils to sites of sterile inflammation. Science 330: 362-6 [PMID:20947763]

122. Miao Z, Premack BA, Wei Z, Wang Y, Gerard C, Showell H, Howard M, Schall TJ and Berahovich R. (2007) Proinflammatory proteases liberate a discrete high-affinity functional FPRL1 (CCR12) ligand from CCL23. J Immunol 178: 7395-404 [PMID:17513790]

123. Miettinen HM, Gripentrog JM and Jesaitis AJ. (1998) Chemotaxis of chinese hamster ovary cells expressing the human neutrophil formyl peptide receptor: role of signal transduction molecules and alpha5beta1 integrin. J Cell Sci 111 ( Pt 14): 1921-8 [PMID:9645940]

124. Migeotte I, Communi D and Parmentier M. (2006) Formyl peptide receptors: a promiscuous subfamily of G protein-coupled receptors controlling immune responses. Cytokine Growth Factor Rev 17: 501-19 [PMID:17084101]

125. Migeotte I, Riboldi E, Franssen JD, Grégoire F, Loison C, Wittamer V, Detheux M, Robberecht P, Costagliola S and Vassart G et al.. (2005) Identification and characterization of an endogenous chemotactic ligand specific for FPRL2. J Exp Med 201: 83-93 [PMID:15623572]

126. Morley AD, King S, Roberts B, Lever S, Teobald B, Fisher A, Cook T, Parker B, Wenlock M and Phillips C et al.. (2012) Lead optimisation of pyrazoles as novel FPR1 antagonists. Bioorg Med Chem Lett 22: 532-6 [PMID:22094028]

127. Mullmann TJ, Cheewatrakoolpong B, Anthes JC, Siegel MI, Egan RW and Billah MM. (1993) Phospholipase $\mathrm{C}$ and phospholipase $\mathrm{D}$ are activated independently of each other in chemotactic peptide-stimulated human neutrophils. J Leukoc Biol 53: 630-5 [PMID:8315346]

128. Murphy PM, Ozçelik T, Kenney RT, Tiffany HL, McDermott D and Francke U. (1992) A structural homologue of the N-formyl peptide receptor. Characterization and chromosome mapping of a peptide chemoattractant receptor family. J Biol Chem 267: 7637-43 [PMID:1373134]

129. Naccache PH, Showell HJ, Becker EL and Sha'afi RI. (1977) Transport of sodium, potassium, and calcium across rabbit polymorphonuclear leukocyte membranes. Effect of chemotactic factor. J Cell Biol 73: 428-44 [PMID:558197]

130. Nanamori M, Cheng X, Mei J, Sang H, Xuan Y, Zhou C, Wang MW and Ye RD. (2004) A novel nonpeptide ligand for formyl peptide receptor-like 1. Mol Pharmacol 66: 1213-22 [PMID:15308762]

131. Nanamori M, He R, Sang H and Ye RD. (2004) Normal cell surface expression and selective loss of functions resulting from Phe110 to Ser and Cys126 to Trp substitutions in the formyl peptide receptor. Immunol Invest 33: 193-212 [PMID:15195697]

132. NCBI. LPHN2 - Ovarian cancer and depression.

133. Niedel JE, Kahane I and Cuatrecasas P. (1979) Receptor-mediated internalization of fluorescent chemotactic peptide by human neutrophils. Science 205: 1412-4 [PMID:472759]

134. Norling LV, Dalli J, Flower RJ, Serhan CN and Perretti M. (2012) Resolvin D1 limits polymorphonuclear leukocyte recruitment to inflammatory loci: receptor-dependent actions. Arterioscler Thromb Vasc Biol 32: 1970-8 [PMID:22499990]

135. Osei-Owusu P, Charlton TM, Kim HK, Missiakas D and Schneewind O. (2019) FPR1 is the plague receptor on host immune cells. Nature 574: 57-62 [PMID:31534221]

136. Otani T, Ikeda S, Lwin H, Arai T, Muramatsu M and Sawabe M. (2011) Polymorphisms of the formylpeptide receptor gene (FPR1) and susceptibility to stomach cancer in 1531 consecutive autopsy cases. Biochem Biophys Res Commun 405: 356-61 [PMID:21216225]

137. Pai JK, Siegel MI, Egan RW and Billah MM. (1988) Phospholipase D catalyzes phospholipid metabolism in chemotactic peptide-stimulated HL-60 granulocytes. J Biol Chem 263: 12472-7 [PMID:3165977]

138. Partida-Sánchez S, Cockayne DA, Monard S, Jacobson EL, Oppenheimer N, Garvy B, Kusser K, Goodrich S, Howard M and Harmsen A et al.. (2001) Cyclic ADP-ribose production by CD38 regulates intracellular calcium release, extracellular calcium influx and chemotaxis in neutrophils and is required for bacterial clearance in vivo. Nat Med 7: 1209-16 [PMID:11689885]

139. Partidá-Sánchez S, Rivero-Nava L, Shi G and Lund FE. (2007) CD38: an ecto-enzyme at the crossroads of innate and adaptive immune responses. Adv Exp Med Biol 590: 171-83 [PMID:17191385]

140. Perez HD, Holmes R, Kelly E, McClary J and Andrews WH. (1992) Cloning of a cDNA encoding a receptor related to the formyl peptide receptor of human neutrophils. Gene 118: 303-4 [PMID:1511907]

141. Perretti M, Chiang N, La M, Fierro IM, Marullo S, Getting SJ, Solito E and Serhan CN. (2002) Endogenous lipid- and peptide-derived anti-inflammatory pathways generated with glucocorticoid and aspirin treatment activate the lipoxin A4 receptor. Nat Med 8: 1296-302 [PMID:12368905]

142. Perretti M, Getting SJ, Solito E, Murphy PM and Gao JL. (2001) Involvement of the receptor for formylated peptides in the in vivo anti-migratory actions of annexin 1 and its mimetics. Am J 
Pathol 158: 1969-73 [PMID:11395373]

143. Petri MH, Laguna-Fernandez A, Tseng CN, Hedin U, Perretti M and Bäck M. (2015) Aspirintriggered 15-epi-lipoxin A4 signals through FPR2/ALX in vascular smooth muscle cells and protects against intimal hyperplasia after carotid ligation. Int J Cardiol 179: 370-2 [PMID:25464488]

144. Pieretti S, Di Giannuario A, De Felice M, Perretti M and Cirino G. (2004) Stimulus-dependent specificity for annexin 1 inhibition of the inflammatory nociceptive response: the involvement of the receptor for formylated peptides. Pain 109: 52-63 [PMID:15082126]

145. Pinilla C, Edwards BS, Appel JR, Yates-Gibbins T, Giulianotti MA, Medina-Franco JL, Young SM, Santos RG, Sklar LA and Houghten RA. (2013) Selective agonists and antagonists of formylpeptide receptors: duplex flow cytometry and mixture-based positional scanning libraries. Mol Pharmacol 84: 314-24 [PMID:23788657]

146. Planagumà A, Domenech T, Jover I, Ramos I, Sentellas S, Malhotra R and Miralpeix M. (2013) Lack of activity of 15-epi-lipoxin A4 on FPR2/ALX and CysLT1 receptors in interleukin-8-driven human neutrophil function. Clin Exp Immunol 173: 298-309 [PMID:23607720]

147. Pozzan T, Lew DP, Wollheim CB and Tsien RY. (1983) Is cytosolic ionized calcium regulating neutrophil activation? Science 221: 1413-5 [PMID:6310757]

148. Prat C, Bestebroer J, de Haas CJ, van Strijp JA and van Kessel KP. (2006) A new staphylococcal anti-inflammatory protein that antagonizes the formyl peptide receptor-like 1. J Immunol 177: 8017-26 [PMID:17114475]

149. Qin CX, May LT, Li R, Cao N, Rosli S, Deo M, Alexander AE, Horlock D, Bourke JE and Yang YH et al.. (2017) Small-molecule-biased formyl peptide receptor agonist compound 17b protects against myocardial ischaemia-reperfusion injury in mice. Nat Commun 8: 14232 [PMID:28169296]

150. Qiu FH, Devchand PR, Wada K and Serhan CN. (2001) Aspirin-triggered lipoxin A4 and lipoxin A4 up-regulate transcriptional corepressor NAB1 in human neutrophils. FASEB J 15: 2736-8 [PMID:11687510]

151. Quehenberger O, Prossnitz ER, Cavanagh SL, Cochrane CG and Ye RD. (1993) Multiple domains of the $\mathrm{N}$-formyl peptide receptor are required for high-affinity ligand binding. Construction and analysis of chimeric N-formyl peptide receptors. J Biol Chem 268: 18167-75 [PMID:8349692]

152. Rabiet MJ, Huet E and Boulay F. (2005) Human mitochondria-derived N-formylated peptides are novel agonists equally active on FPR and FPRL1, while Listeria monocytogenes-derived peptides preferentially activate FPR. Eur J Immunol 35: 2486-95 [PMID:16025565]

153. Rabiet MJ, Macari L, Dahlgren C and Boulay F. (2011) N-formyl peptide receptor 3 (FPR3) departs from the homologous FPR2/ALX receptor with regard to the major processes governing chemoattractant receptor regulation, expression at the cell surface, and phosphorylation. $J$ Biol Chem 286: 26718-31 [PMID:21543323]

154. Resnati M, Pallavicini I, Wang JM, Oppenheim J, Serhan CN, Romano M and Blasi F. (2002) The fibrinolytic receptor for urokinase activates the $\mathrm{G}$ protein-coupled chemotactic receptor FPRL1/LXA4R. Proc Natl Acad Sci USA 99: 1359-64 [PMID:11818541]

155. Rot A, Henderson LE, Copeland TD and Leonard EJ. (1987) A series of six ligands for the human formyl peptide receptor: tetrapeptides with high chemotactic potency and efficacy. Proc Natl Acad Sci USA 84: 7967-71 [PMID:2825171]

156. Sahagun-Ruiz A, Colla JS, Juhn J, Gao JL, Murphy PM and McDermott DH. (2001) Contrasting evolution of the human leukocyte N-formylpeptide receptor subtypes FPR and FPRL1R. Genes Immun 2: 335-42 [PMID:11607790]

157. Sawmynaden P and Perretti M. (2006) Glucocorticoid upregulation of the annexin-A1 receptor in leukocytes. Biochem Biophys Res Commun 349: 1351-5 [PMID:16973129]

158. Schepetkin IA, Kirpotina LN, Khlebnikov AI and Quinn MT. (2007) High-throughput screening for small-molecule activators of neutrophils: identification of novel $\mathrm{N}$-formyl peptide receptor agonists. Mol Pharmacol 71: 1061-74 [PMID:17229869]

159. Schiffmann E, Corcoran BA and Wahl SM. (1975) N-formylmethionyl peptides as chemoattractants for leucocytes. Proc Natl Acad Sci USA 72: 1059-62 [PMID:1093163]

160. Schiffmann E, Showell HV, Corcoran BA, Ward PA, Smith E and Becker EL. (1975) The isolation and partial characterization of neutrophil chemotactic factors from Escherichia coli. J Immunol 114: 1831-7 [PMID:165239]

161. Schreiber RE, Prossnitz ER, Ye RD, Cochrane CG, Jesaitis AJ and Bokoch GM. (1993) Reconstitution of recombinant $\mathrm{N}$-formyl chemotactic peptide receptor with G protein. J Leukoc Biol 53: 470-4 [PMID:8482927]

162. Seifert R and Wenzel-Seifert K. (2001) Defective Gi protein coupling in two formyl peptide receptor mutants associated with localized juvenile periodontitis. J Biol Chem 276: 42043-9 [PMID:11559706]

163. Seo JK, Choi SY, Kim Y, Baek SH, Kim KT, Chae CB, Lambeth JD, Suh PG and Ryu SH. (1997) A peptide with unique receptor specificity: stimulation of phosphoinositide hydrolysis and induction of superoxide generation in human neutrophils. J Immunol 158: 1895-901 
[PMID:9029131]

164. Sergeant S and McPhail LC. (2007) Measurement of phospholipid metabolism in intact neutrophils. Methods Mol Biol 412: 69-83 [PMID:18453106]

165. Sharma VP, DesMarais V, Sumners C, Shaw G and Narang A. (2008) Immunostaining evidence for PI(4,5)P2 localization at the leading edge of chemoattractant-stimulated HL-60 cells. $J$ Leukoc Biol 84: 440-7 [PMID:18477691]

166. Shen W, Proost P, Li B, Gong W, Le Y, Sargeant R, Murphy PM, Van Damme J and Wang JM. (2000) Activation of the chemotactic peptide receptor FPRL1 in monocytes phosphorylates the chemokine receptor CCR5 and attenuates cell responses to selected chemokines. Biochem Biophys Res Commun 272: 276-83 [PMID:10872839]

167. Sherman F, Stewart JW and Tsunasawa S. (1985) Methionine or not methionine at the beginning of a protein. Bioessays 3: 27-31 [PMID:3024631]

168. Shin EH, Lee HY, Kim SD, Jo SH, Kim MK, Park KS, Lee H and Bae YS. (2006) Trp-Arg-Trp-TrpTrp-Trp antagonizes formyl peptide receptor like 2-mediated signaling. Biochem Biophys Res Commun 341: 1317-22 [PMID:16476585]

169. Showell HJ, Freer RJ, Zigmond SH, Schiffmann E, Aswanikumar S, Corcoran B and Becker EL. (1976) The structure-activity relations of synthetic peptides as chemotactic factors and inducers of lysosomal secretion for neutrophils. J Exp Med 143: 1154-69 [PMID:1262785]

170. Simiele F, Recchiuti A, Mattoscio D, De Luca A, Cianci E, Franchi S, Gatta V, Parolari A, Werba JP and Camera $M$ et al.. (2012) Transcriptional regulation of the human FPR2/ALX gene: evidence of a heritable genetic variant that impairs promoter activity. FASEB J 26: 1323-33 [PMID:22131270]

171. Sodin-Semrl S, Spagnolo A, Barbaro B, Varga J and Fiore S. (2004) Lipoxin A4 counteracts synergistic activation of human fibroblast-like synoviocytes. Int J Immunopathol Pharmacol 17: 15-25 [PMID:15000862]

172. Sodin-Semrl S, Spagnolo A, Mikus R, Barbaro B, Varga J and Fiore S. (2004) Opposing regulation of interleukin-8 and NF-kappaB responses by lipoxin A4 and serum amyloid A via the common lipoxin A receptor. Int J Immunopathol Pharmacol 17: 145-56 [PMID:15171815]

173. Sodin-Semrl S, Taddeo B, Tseng D, Varga J and Fiore S. (2000) Lipoxin A4 inhibits IL-1 betainduced IL-6, IL-8, and matrix metalloproteinase-3 production in human synovial fibroblasts and enhances synthesis of tissue inhibitors of metalloproteinases. J Immunol 164: 2660-6 [PMID:10679106]

174. Southgate EL, He RL, Gao JL, Murphy PM, Nanamori M and Ye RD. (2008) Identification of formyl peptides from Listeria monocytogenes and Staphylococcus aureus as potent chemoattractants for mouse neutrophils. J Immunol 181: 1429-37 [PMID:18606697]

175. Stalder AK, Lott D, Strasser DS, Cruz HG, Krause A, Groenen PM and Dingemanse J. (2017) Biomarker-guided clinical development of the first-in-class anti-inflammatory FPR2/ALX agonist ACT-389949. Br J Clin Pharmacol 83: 476-486 [PMID:27730665]

176. Stenfeldt AL, Karlsson J, Wennerås C, Bylund J, Fu H and Dahlgren C. (2007) Cyclosporin H, Boc-MLF and Boc-FLFLF are antagonists that preferentially inhibit activity triggered through the formyl peptide receptor. Inflammation 30: 224-9 [PMID:17687636]

177. Su SB, Gao Jl, Gong Wh, Dunlop NM, Murphy PM, Oppenheim JJ and Wang JM. (1999) T21/DP107, A synthetic leucine zipper-like domain of the HIV-1 envelope gp41, attracts and activates human phagocytes by using G-protein-coupled formyl peptide receptors. $J$ Immunol 162: 5924-30 [PMID:10229829]

178. Su SB, Gong W, Gao JL, Shen W, Murphy PM, Oppenheim JJ and Wang JM. (1999) A seventransmembrane, G protein-coupled receptor, FPRL1, mediates the chemotactic activity of serum amyloid A for human phagocytic cells. J Exp Med 189: 395-402 [PMID:9892621]

179. Su SB, Gong WH, Gao JL, Shen WP, Grimm MC, Deng X, Murphy PM, Oppenheim JJ and Wang JM. (1999) T20/DP178, an ectodomain peptide of human immunodeficiency virus type $1 \mathrm{gp} 41$, is an activator of human phagocyte N-formyl peptide receptor. Blood 93: 3885-92 [PMID:10339497]

180. Sun R, Iribarren P, Zhang N, Zhou Y, Gong W, Cho EH, Lockett S, Chertov O, Bednar F, Rogers TJ, Oppenheim JJ and Wang JM. (2004) Identification of neutrophil granule protein cathepsin G as a novel chemotactic agonist for the $\mathrm{G}$ protein-coupled formyl peptide receptor. J Immunology 173: 428-436 [PMID:15210802]

181. Takano T, Fiore S, Maddox JF, Brady HR, Petasis NA and Serhan CN. (1997) Aspirin-triggered 15-epi-lipoxin A4 (LXA4) and LXA4 stable analogues are potent inhibitors of acute inflammation: evidence for anti-inflammatory receptors. J Exp Med 185: 1693-704 [PMID:9151906]

182. Takenawa T, Ishitoya J, Homma Y, Kato M and Nagai Y. (1985) Role of enhanced inositol phospholipid metabolism in neutrophil activation. Biochem Pharmacol 34: 1931-5 [PMID:2988563]

183. Tiffany HL, Lavigne MC, Cui YH, Wang JM, Leto TL, Gao JL and Murphy PM. (2001) Amyloidbeta induces chemotaxis and oxidant stress by acting at formylpeptide receptor 2 , a $\mathrm{G}$ proteincoupled receptor expressed in phagocytes and brain. J Biol Chem 276: 23645-52 
[PMID:11316806]

184. Unitt J, Fagura M, Phillips T, King S, Perry M, Morley A, MacDonald C, Weaver R, Christie J and Barber S et al.. (2011) Discovery of small molecule human FPR1 receptor antagonists. Bioorg Med Chem Lett 21: 2991-7 [PMID:21486695]

185. Waechter V, Marti-Jaun J, Weber A, Madi ZL and Hersberger M. (2012) No evidence for the involvement of the lipoxin A4 receptor (FPR2/ALX ) gene in the susceptibility to coronary artery disease. Clin Chem Lab Med 50: 177-9 [PMID:22734147]

186. Walther A, Riehemann K and Gerke V. (2000) A novel ligand of the formyl peptide receptor: annexin I regulates neutrophil extravasation by interacting with the FPR. Mol Cell 5: 831-40 [PMID:10882119]

187. Wang CS and Baker OJ. (2018) The G-Protein-Coupled Receptor ALX/Fpr2 Regulates Adaptive Immune Responses in Mouse Submandibular Glands. Am J Pathol 188: 1555-1562 [PMID:29684359]

188. Wang X and Zhang S. (2011) Production of a bioengineered G-protein coupled receptor of human formyl peptide receptor 3. PLoS ONE 6: e23076 [PMID:21853070]

189. Wenzel-Seifert K, Grünbaum L and Seifert R. (1991) Differential inhibition of human neutrophil activation by cyclosporins $\mathrm{A}, \mathrm{D}$, and $\mathrm{H}$. Cyclosporin $\mathrm{H}$ is a potent and effective inhibitor of formyl peptide-induced superoxide formation. J Immunol 147: 1940-6 [PMID:1653806]

190. Wenzel-Seifert K and Seifert R. (1993) Cyclosporin H is a potent and selective formyl peptide receptor antagonist. Comparison with N-t-butoxycarbonyl-L-phenylalanyl-L-leucyl-Lphenylalanyl-L- leucyl-L-phenylalanine and cyclosporins A, B, C, D, and E. J Immunol 150: 45919 [PMID:8387097]

191. Williams LT, Snyderman R, Pike MC and Lefkowitz RJ. (1977) Specific receptor sites for chemotactic peptides on human polymorphonuclear leukocytes. Proc Natl Acad Sci USA 74: 1204-8 [PMID:265563]

192. Yamamoto Y, Kanazawa T, Shimamura M, Ueki M and Hazato T. (1997) Inhibitory effects of spinorphin, a novel endogenous regulator, on chemotaxis, O2- generation, and exocytosis by $\mathrm{N}$ formylmethionyl-leucyl-phenylalanine (FMLP)-stimulated neutrophils. Biochem Pharmacol 54: 695-701 [PMID:9310346]

193. Yan $\mathrm{P}$, Nanamori M, Sun M, Zhou C, Cheng N, Li N, Zheng W, Xiao L, Xie X and Ye RD et al.. (2006) The immunosuppressant cyclosporin A antagonizes human formyl peptide receptor through inhibition of cognate ligand binding. J Immunol 177: 7050-8 [PMID:17082621]

194. Yang D, Chen Q, Gertz B, He R, Phulsuksombati M, Ye RD and Oppenheim JJ. (2002) Human dendritic cells express functional formyl peptide receptor-like-2 (FPRL2) throughout maturation. J Leukoc Biol 72: 598-607 [PMID:12223529]

195. Yang EM, Kim SH, Kim NH and Park HS. (2010) The genetic association of the FPRL1 promoter polymorphism with chronic urticaria in a Korean population. Ann Allergy Asthma Immunol 105: 96-7 [PMID:20642210]

196. Ye RD, Boulay F, Wang JM, Dahlgren C, Gerard C, Parmentier M, Serhan CN and Murphy PM. (2009) International Union of Basic and Clinical Pharmacology. LXXIII. Nomenclature for the formyl peptide receptor (FPR) family. Pharmacol Rev 61: 119-61 [PMID:19498085]

197. Ye RD, Cavanagh SL, Quehenberger O, Prossnitz ER and Cochrane CG. (1992) Isolation of a cDNA that encodes a novel granulocyte N-formyl peptide receptor. Biochem Biophys Res Commun 184: 582-9 [PMID:1374236]

198. Ying G, Iribarren P, Zhou Y, Gong W, Zhang N, Yu ZX, Le Y, Cui Y and Wang JM. (2004) Humanin, a newly identified neuroprotective factor, uses the G protein-coupled formylpeptide receptor-like-1 as a functional receptor. J Immunol 172: 7078-85 [PMID:15153530]

199. Young SM, Bologa C, Prossnitz ER, Oprea TI, Sklar LA and Edwards BS. (2005) High-throughput screening with HyperCyt flow cytometry to detect small molecule formylpeptide receptor ligands. J Biomol Screen 10: 374-82 [PMID:15964939]

200. Zhang Q, Raoof M, Chen Y, Sumi Y, Sursal T, Junger W, Brohi K, Itagaki K and Hauser CJ. (2010) Circulating mitochondrial DAMPs cause inflammatory responses to injury. Nature 464: 104-7 [PMID:20203610]

201. Zhang S, Gong H, Ge Y and Ye RD. (2020) Biased allosteric modulation of formyl peptide receptor 2 leads to distinct receptor conformational states for pro- and anti-inflammatory signaling. Pharmacol Res 161: 105117 [PMID:32768626]

202. Zhou C, Zhang S, Nanamori M, Zhang Y, Liu Q, Li N, Sun M, Tian J, Ye PP and Cheng N et al. (2007) Pharmacological characterization of a novel nonpeptide antagonist for formyl peptide receptor-like 1. Mol Pharmacol 72: 976-83 [PMID:17652444]

203. Zhuang Y, Liu H, Edward Zhou X, Kumar Verma R, de Waal PW, Jang W, Xu TH, Wang L, Meng $\mathrm{X}$ and Zhao $\mathrm{G}$ et al.. (2020) Structure of formylpeptide receptor $2-\mathrm{G}_{\mathrm{i}}$ complex reveals insights into ligand recognition and signaling. Nat Commun 11: 885 [PMID:32060286]

204. Zigmond SH. (1977) Ability of polymorphonuclear leukocytes to orient in gradients of chemotactic factors. J Cell Biol 75: 606-16 [PMID:264125] 
